SHS Web of Conferences 23,03002 (2016)

DOI: $10.1051 /$ shsconf/ 20162303002

(C) Owned by the authors, published by EDP Sciences, 2016

\title{
UHT SKIM COCONUT MILK PRODUCTION AND ITS QUALITY
}

\author{
Krittiya Khuenpet, Weerachet Jittanit*, Napat Hongha \\ and Sajja Pairojkul \\ Department of Food Science and Technology, Faculty of Agro-Industry, \\ Kasetsart University,50 Ngam Wong Wan Road, Chatuchak, Bangkok 10900, Thailand. \\ E-mail: fagiwcj@ku.ac.th
}

\begin{abstract}
The current study is based upon the potential value of low-fat coconut milk in market due to increasing health concerns in people nowadays. Skim coconut milk can be used as a food ingredient that requires coconut milk flavor but excluding fat. The fundamental objectives of this study were to examine the methods for skim coconut milk production and comparison of its quality with normal coconut milk. The results of this study indicated that the UHT skim coconut milk can be prepared by separating fat through a cream separator, adding CMC and Montanox 60 at 0.6 and $0.6 \% \mathrm{w} / \mathrm{v}$ respectively, two-stage homogenizing at $1,500 / 500 \mathrm{psi}$, and then UHT sterilizing at $140{ }^{\circ} \mathrm{C}$ for $4 \mathrm{~s}\left(\mathrm{~F}_{\mathrm{o}} \approx 5 \mathrm{~min}\right)$. It appeared that the remaining fat content in skim coconut milk was less than $1 \%$. The addition of the CMC and Montanox 60 could obviously raise the stability of coconut milk emulsion and caused the increase of viscosity of the skim coconut milk specimen. The skim coconut milk had higher specific gravity and obviously darker than the higher-fat samples. The sensorial characteristic of skim coconut milk samples were different from the normal coconut milk.
\end{abstract}

Keywords: skim coconut milk, cream separation, CMC, Montanox 60, UHT

\section{INTRODUCTION}

Coconut milk has been used as a vital ingredient in a variety of Asian foods and desserts especially in China, India and Southeast Asia. In general, coconut milk is milky white juice prepared by pressing grated coconut flesh with or without added water. The composition of fresh coconut milk typically contains aqueous $55 \pm 3 \%$, fat $37 \pm 2 \%$ and protein $8 \pm 2 \%$ (Seow \& Gwee, 1997). According to its composition, coconut milk is an oil-in-water emulsion which is stabilized by natural emulsifiers such as globulins and albumins proteins 
and phospholipids (Onsaard et al., 2005). Fat is considered as a key component because it affects on the appearance and sensorial attributes of coconut milk products and the food that applied them as an ingredient.

Although, most foods that require coconut milk as an ingredient prefer the coconut milk that contains fat content in the range of $17-22 \%$, the low-fat coconut milk is also interesting merchandise that should be able to propose to the marketplace. It is because during the last decade, the trend of food product development has been spotlighted on healthy food. A myriad of people avoid consuming fat for the reason that it leads to obesity and several diseases such as high blood pressure and coronary heart disease. According to the Codex Standard for Aqueous Coconut Products, coconut milk with fat content of less than $3.75 \%$ is classified as "skim coconut milk". The skim coconut milk can be used as an ingredient in either food or sweet that requires coconut milk flavor but not the high fat.

The skim coconut milk can be manufactured by separating cream or oil from the raw coconut milk. Marina et al. (2009) extracted cream from the fresh coconut milk and then broke the cream emulsion to obtain virgin coconut oil. This process is called wet processing. Another method to divide cream from the coconut milk is centrifugation. After centrifugation, the coconut milk would be separated by the density of each parts to be three phases (Naik et al., 2012) including fat phase (coconut cream), aqueous phase (low-fat coconut milk) and solid phase (insoluble protein).

In order to preserve the quality and extend the storage life of coconut milk, a number of thermal processing methods can be applied such as pasteurization, sterilization and ultrahigh temperature (UHT) treatment. Different methods usually result in dissimilar feature, storage condition and product life. Wattanapahu et al. (2012) reported that the odor, flavor and appearance of coconut milk products related to the applied thermal processing scheme. Normally, if the demanded shelf life is longer than 6 months, the UHT processing would be an attractive method due to its ability to kill microorganisms while maintaining the product quality.

During storage of coconut milk, separation of coconut milk into two layers is caused by creaming. Creaming is the result of upward movement of the oil droplets due to their lower density than the aqueous continuous phase. This phenomenon usually occurs leading to the layer separation and subsequently the consumer unsatisfactory. Therefore, the addition of emulsifier and stabilizer together with the application of homogenization process are considered necessary when commercially manufacturing coconut milk product (Simuang et al., 2004). According to Phungamngoen et al. (2004), the carboxymethyl cellulose (CMC), 
Montanox 60 and Montane 80 could assist maintaining the stability and fine appearance of coconut milk emulsion after commercially sterilization process $\left(121.1{ }^{\circ} \mathrm{C}\right.$ for $60 \mathrm{~min} ; \mathrm{F}_{0}=5$ min). However, adding CMC and Montanox 60 at 0.6 and $0.6 \% \mathrm{w} / \mathrm{v}$ was recommended for improving the quality of canned high fat coconut milk (fat content $30 \%$ ) and could provide the emulsion stability of higher than $80 \%$ no curding and no significantly difference in colors comparing to fresh coconut milk after heat treatment (Jirapeangtong et al., 2008).

Due to the lacking of the research in the area of skim coconut milk production, in this study the coconut milk samples were prepared, separated the fat, added with some additives, homogenized and exposed to UHT process. The fat content, physical and sensorial attributes of various UHT samples were determined and compared. The objectives were to basically investigate the methods for producing skim coconut milk and compare its quality with the higher-fat samples prepared by various conditions.

\section{MATERIALS AND METHODS}

\subsection{Raw Materials}

Fresh coconut milk was purchased from the local market nearby Kasetsart University, Bangkok, Thailand. The fresh coconut milk was pasteurized in a stainless steel pot using LPG gas stove as a heat source. The samples were heated until reaching the temperature of $85^{\circ} \mathrm{C}$ and then held the temperature for at least $1 \mathrm{~min}$ before cooling in order to prevent spoilage prior to testing. After pasteurization, the samples were divided into 5 portions. One portion was kept in the sterilized bottle and stored at $4{ }^{\circ} \mathrm{C}$ for using as a control sample whereas the rests were exposed to various procedures as illustrated in Table 1. The schematic diagram representing the preparation steps of sample no. 5 is as Figure 1.

Table 1. The treatment conditions of coconut milk samples

\begin{tabular}{cccccc}
\hline Sample & & \multicolumn{5}{c}{ Conditions } \\
\cline { 3 - 6 } no. & Treatment & Pasteurization & $\begin{array}{c}\text { Fat } \\
\text { separation }\end{array}$ & $\begin{array}{c}\text { Adding } \\
\text { emulsifier }\end{array}$ & Homogenization UHT \\
\hline 1 & & $\checkmark$ & $\checkmark$ & $\checkmark$ \\
2 & Control & UHT & $\checkmark$ & $\checkmark$ & $\checkmark$ \\
3 & Adding Emulsifiers & $\checkmark$ & & $\checkmark$ & $\checkmark$ \\
4 & Fat Separation (FS) + & $\checkmark$ & $\checkmark$ & & $\checkmark$ \\
& UHT & & & &
\end{tabular}




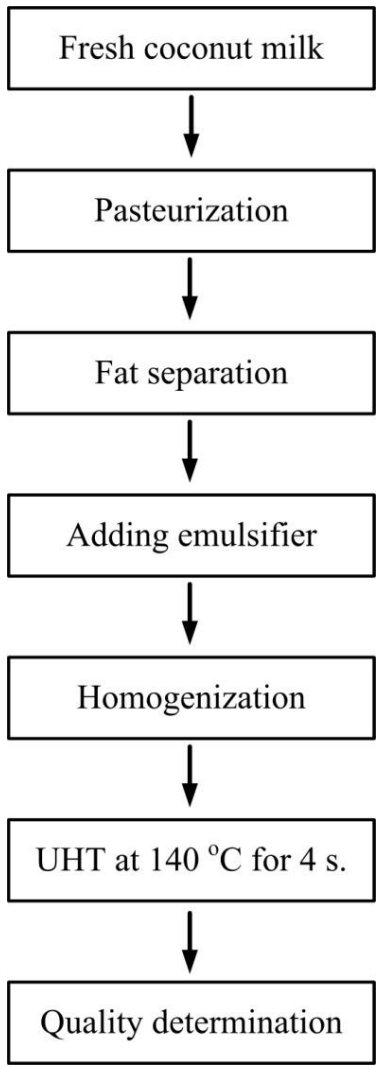

Figure 1 The preparation steps of sample no. 5

\subsection{Fat Separation}

The coconut milk specimens were separated their fat by centrifugation technique applying the cream separator (Elecrem, Model Elecrem1, France). Due to the extremely high fat content in the separated cream, the coconut milk after cream separation was deemed as the skim coconut milk sample.

\subsection{The Addition of Emulsifier and Stabilizer}

The Carboxymethyl cellulose (CMC) and Montanox 60 were used as stabilizer and emulsifier respectively. Both additives were obtained from Adinop Co., Ltd. in Bangkok, Thailand. CMC and Montanox 60 at 0.6 and $0.6 \% \mathrm{w} / \mathrm{v}$ was used according to the study of Phungamngoen et al. (2004). In order to facilitate the dissolution of these additives, the 
coconut milk samples were warmed to approximately $80{ }^{\circ} \mathrm{C}$ before adding stabilizer and emulsifier and stirring by blender (Philips, Model HR 2061, Netherlands).

\subsection{Homogenization}

The homogenization process was conducted in a two-stage homogenizer (APV, Model 15MR-8TA, USA) at 1,500/500 psi.

\subsection{UHT Sterilization}

The UHT sterilization was carried out using the lab-scale UHT/HTST machine (MicroThermics, Model Lab 25 EHV Hybrid, USA). The UHT condition was sterilization temperature at $140{ }^{\circ} \mathrm{C}$ for $4 \mathrm{~s}\left(\mathrm{~F}_{\mathrm{o}} \approx 5 \mathrm{~min}\right.$; APCC, 1994). The UHT samples were aseptically filled into the sterilized glass bottles under the clean fill hood and kept at room temperature before the quality determination.

\subsection{Quality Determination}

The quality of coconut milk samples in aspects of emulsion stability, fat content, viscosity, specific gravity and color were determined. The emulsion stability was evaluated by applying the separation on standing method (Lamar et al., 1976). For this method, the coconut milk $(30 \mathrm{ml})$ was transferred into a test tube, covered and stored at ambient temperature (approximately $30{ }^{\circ} \mathrm{C}$ ). Then, the aggregation would cause the separation of samples to be two layers comprising an opaque cream layer on the top and a transparent serum layer at the bottom. The thickness values of cream layer were measured and recorded at $30 \mathrm{~min}, 1,2,24$ and $72 \mathrm{~h}$. The total height of the emulsion in the test tube $\left(\mathrm{H}_{\mathrm{E}}\right)$ and the height of the aqueous layer $\left(\mathrm{H}_{\mathrm{S}}\right)$ were measured and the extent of creaming was characterized by a creaming index $=100 *\left(\mathrm{H}_{\mathrm{S}} / \mathrm{H}_{\mathrm{E}}\right)($ Raghavendra $\&$ Raghavarao, 2010). The fat content was determined by applying a centrifuge (Furke Gerber, Model Supervario-N, Germany) following the Babcock method (Kleyn et al., 2001). The viscosity, specific gravity and color $\left(\mathrm{L}^{*}, \mathrm{a}^{*}\right.$ and $\mathrm{b}^{*}$ ) were measured by a digital viscometer (Brookfield, Model HBDV-II ${ }^{+}$, USA with spindle no.1 at $50 \mathrm{rpm}$.), hydrometer (Nikkei, Japan) and colorimeter (HunterLab, Model Miniscan XE, USA) respectively. All the quality determinations were conducted in triplicate except the viscosity that was measured merely once due to the limited remaining amount of samples. 
Apart from the quality attributes that are previously described, the sensorial quality of coconut milk samples were also evaluated in aspects of color, odor, taste, texture and overall characteristic by 30 panelists who were the students in the faculty using the difference testing. This test was used to determine a difference from control. There were 6 samples for sensory test. A control (sample no.1; labeled C) was presented to the panelist together with several coded samples (sample no.2-5) including blind control (control sample with the numerical labeled). Each sample was compared with the control sample on the sensorial characteristic. The sensorial qualities were evaluated using scores $0-5(0=$ not different and $5=$ extremely different). The result can be assigned to the ratings.

The software package Statistica 5.5 StatSoft $^{\mathrm{TM}}$ (supplied by StatSoft, Inc. Tulsa, OK 74104 USA) was used for the analysis of variance (ANOVA) and a Duncan's multiple range test in the statistical analysis.

\section{RESULTS AND DISCUSSION}

After finishing the preparation of all the coconut milk samples, they were shaken and then left for 15 min prior to be taken a photograph as shown in Figure 2. It is obvious that the samples no. 1, 2 and 4 were unstable and rapidly separated to be two different phases comprising a denser aqueous phase at the lower part and a lighter cream phase on the top. On the other hand, the samples no. 3 and 5 were still homogeneous emulsion. The explanation for this phenomenon is that the coconut milk samples no. 1, 2 and 4 were not added with any emulsifier and stabilizer while the $\mathrm{CMC}$ and Montanox 60 were filled into the remaining specimens at $0.6 \% \mathrm{w} / \mathrm{v}$ for both additives. This result implied that the natural protein existing in the coconut milk is not adequate to stabilize the fat globules; as a result, to improve the stability of coconut milk emulsion, the stabilizer and emulsifier should be applied during the manufacturing process (Monera \& Del Reario; 1982). Sringam (1986) concluded that heat treatment, type and quantity of emulsifier and homogenization had significant effects on the coconut milk stability. Moreover, if specifically considering the sample no. 4 which was separated its cream by centrifugation technique prior to homogenization and UHT processes, the layer separation still occurred apparently. This indicated that there were some fats or light compositions remained in the sample after the cream separation process. 


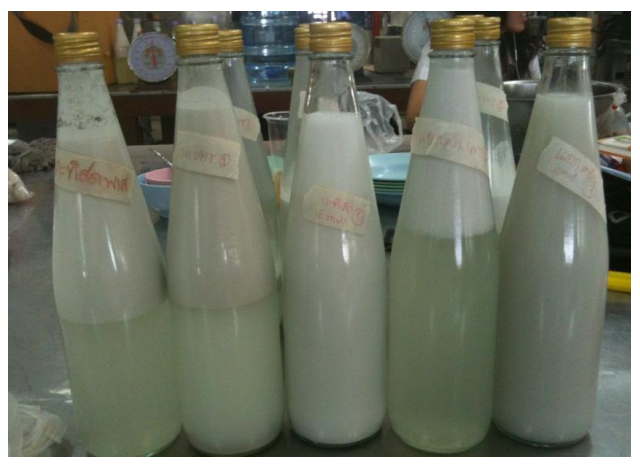

(1) (2) (3) (4) (5)

Figure 2 The appearance of samples no. 1 - 5 after shaking and leaving for 15 min.

Apart from the photograph in Figure 2, the emulsion stability was quantitatively evaluated by applying the separation on standing method as mentioned earlier. For this method, the thickness values and creaming index of cream layer were measured and calculated at each time step as the results shown in Figure $3(a, b)$. The total height of the sample in the test tube was about $10.5 \mathrm{~cm}$. The analysis of this result was carried out in conjunction with the values of measured fat content indicated in Table 2.

After considering the samples no. 1 and 2, it appeared that their emulsion stability were in the same trend whereas their fat contents were also similar that were 8.83 and $9.92 \%$ respectively. From the graph 3 (a), the height of the separated cream layer of sample no.1 and 2 was roughly $5 \mathrm{~cm}$ at $30 \mathrm{~min}$ and then continuously decreased along the subsequent times until reaching at about $2.5 \mathrm{~cm}$ at $72 \mathrm{~h}$. Conversely, the serum layer at the bottom became clearer and higher along the standing time as shown in Table 3. The decrease of the cream layer height can be explained by the denser packing of the cream layer along the time. This process is called the coalescence of fat that occurs from the fat globule from one droplet penetrated into another droplet (Walstra, 2003). For the sample no. 3 that had fat content insignificantly different from sample no. 2, it appeared that after $30 \mathrm{~min}$ the thickness of separated cream layer was rather high that was $6.3 \mathrm{~cm}$ and then continuously lessened until reaching to about $1.5 \mathrm{~cm}$ at $72 \mathrm{~h}$.

However, if looking on the photographs in Table 3, it is apparent that the layer at the bottom half of sample no. 3 was more turbid than sample no. 1. Furthermore, although the thickness of cream layer of sample no. 3 was broad after $30 \mathrm{~min}$, its color was not as intense as that of sample no. 1. The addition of CMC and Montanox 60 must be the cause of this 
circumstance because their functions resulted in the better dissipation of fat in water leading to the subsequently ambiguous separation. Montanox 60, represented an emulsifier, was adsorbed to the surface of fat droplets preventing the aggregation of the fat droplets while CMC caused an increase in viscosity of continuous phase therefore retarded the gravitational separation of the droplets (McClements, 1999; Klinkesorn et al., 2004; Phungamngoen et al., 2004; Jirapeangtong et al., 2008). The decreasing cream layer height along the time can be explained by the same reason as samples no. 1 and 2 .

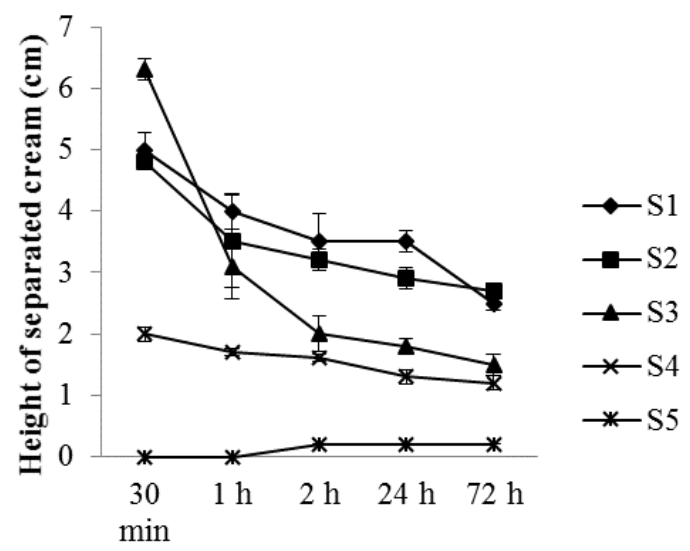

Standing time

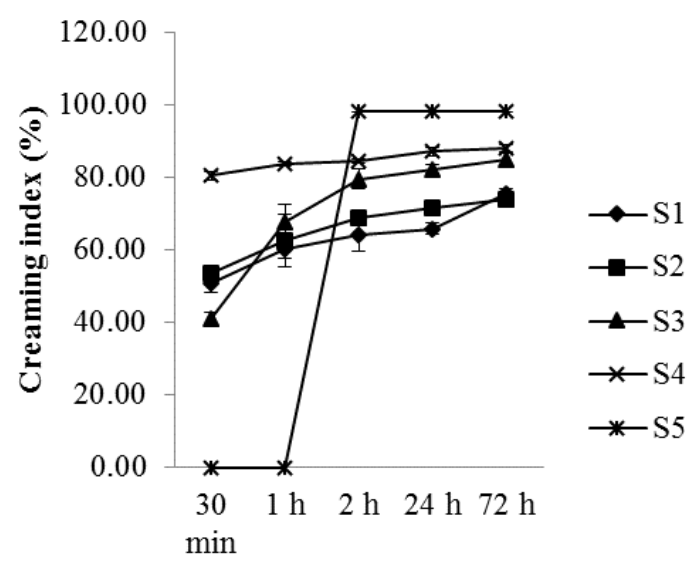

Standing time

(a)

(b)

Figure 3. Height of separated cream layer (a) and creaming index (b) of coconut milk samples no. $1-5$.

The non-enzymatic browning reaction such as Maillard reaction was likely to be expedited by the heat of UHT process causing the darker color of sample no.3. In addition, it has an interesting point from the photographs of sample no. 3 at 24 and $72 \mathrm{~h}$. That is the occurring of sediment at the bottom of the test tube. It was expected that this sediment should be protein that was denatured by the UHT treatment. Demetriades et al. (1997) showed that the emulsions stabilized by globular proteins often partially destabilize when heated above the denaturation temperature of the proteins. Phungamngoen et al. (2004) pointed out that apart from binding the fat to water, Montanox 60 can also binding denatured proteins to the oil in water emulsion. So, in order to reduce the coagulation of protein in coconut milk after 
heat treatment, a sufficient amount of Montanox 60 must be applied. For the skim coconut milk consisting of samples no. 4 and 5 that had fat content of 0.83 and $0.67 \%$ respectively, it was unsurprising that the heights of their separated cream layers were less than those of the other samples due to their fat content especially in the case of adding CMC and Montanox 60 that can assist the suspension of fat globules in water.

According to this result, it was clear that the addition of some emulsifier and stabilizer is necessary for raising the stability of coconut milk emulsion especially in case of high-fat coconut milk. The appropriate proportions of the emulsifier and stabilizer normally depend on the composition of product; so, further study must be done to determine the suitable amount for applying in the skim coconut milk product.

Similarly, emulsion stability of coconut milk was able to quantify by creaming index. From Figure 3(b), it can be observed that sample no.5 presented emulsion stability during $1 \mathrm{~h}$ after that the thin cream layer separation occurred certainly. For other samples, those treatments showed the creaming index varied from $50.79-80.32 \%$ (30 $\mathrm{min}$ ) to $73.65-$ 87.94\% (72 h). Onsaard et al. (2006) reported that higher the creaming index, faster the droplets move and therefore more droplet aggregation occurs.

The viscosity is an important characteristic of liquid food because of its affect on the appearance and the consumer preference. It was found that the viscosity of coconut milk samples were in the range between 12.8-33.6 cP as shown in Table 2. Samples no. 1-3 which had comparable fat contents of around $8.8-10.17 \%$ had the viscosity approximately 25.6-27.2 $\mathrm{cP}$. On the other hand, the much lower viscosity value was found for the skim coconut milk without adding CMC and Montanox 60, sample no.4. Thus, the fat globule in the emulsion must have positive correlation with the viscosity of coconut milk. Simuang et al. (2004) measured the viscosity of coconut milk that had fat contents between $15-30 \%$ and found that the viscosity significantly increased along the increasing fat contents. Nonetheless, the sample no. 5 that had insignificant difference of fat content from sample no. 4 was obviously more viscous than the other samples. The addition of CMC and Montanox 60 accounted for this occurrence due to their functions. Although these additives were also filled into the sample no. 3 , the viscosity of sample was not different from the sample 2 because in this case the $\mathrm{CMC}$ and Montanox 60 were interacted with the larger amount of fat globules to emulsify and stabilize them in the emulsion leading to less influence on the sample viscosity. The experimental results indicated that the skim coconut milk sample with the addition of CMC and Montanox 60 at $0.6: 0.6 \% \mathrm{w} / \mathrm{v}$ was slightly more viscous than the coconut milk samples without fat separation. 
The specific gravity of product is vital for the design of packaging. The specific gravity values of all samples were close to 1 because their main composition was water. It was noticed that the skim coconut milk samples had higher specific gravity than the higherfat samples. It is because the fat has lower density than water. Referring to Ishiaq \& Odeyemi (2012), the specific gravity values of coconut milk and coconut oil in their study were 1.008 and 0.915 respectively indicating that the coconut fat was apparently lighter than coconut milk.

Color of product obviously influences on the consumer acceptance. In this study, the control sample had the $L^{*}$ and $b^{*}$ values similar to those of the fresh coconut milk in the study of Phungamngoen et al. (2004) which were 77.92 and 4.85 respectively. As shown in Table 2, the lightness and greenness of skim coconut milk samples were significant different from the samples no. $1-3$. Moreover, skim coconut milk with the addition of CMC and Montanox 60, sample no. 5, had the negative $b^{*}$ values. This result indicated that fat content affected on the lightness and greenness of coconut milk. The lower fat content leaded to the lower lightness and higher greenness whereas the addition of CMC and Montanox 60 was likely to lessen the yellowness of samples. The emulsifier and stabilizer helped increasing the uniformly dispersion of fat and also other solids in the emulsion leading to the less yellowness of sample as a whole. In general, it can be stated that the skim coconut milk had less intense of color than the sample no. 1-3. The finding in this work went along with the study of Chantrapornchai et al. (1999) which studied the color of oil-in-water emulsions (fat $0-20 \% \mathrm{wt}$ ) and reported that lightness of samples was higher when increasing the fat content. It is because fat can raise the dispersion and reflectance of light (Chanamai \& McClements, 2000). 


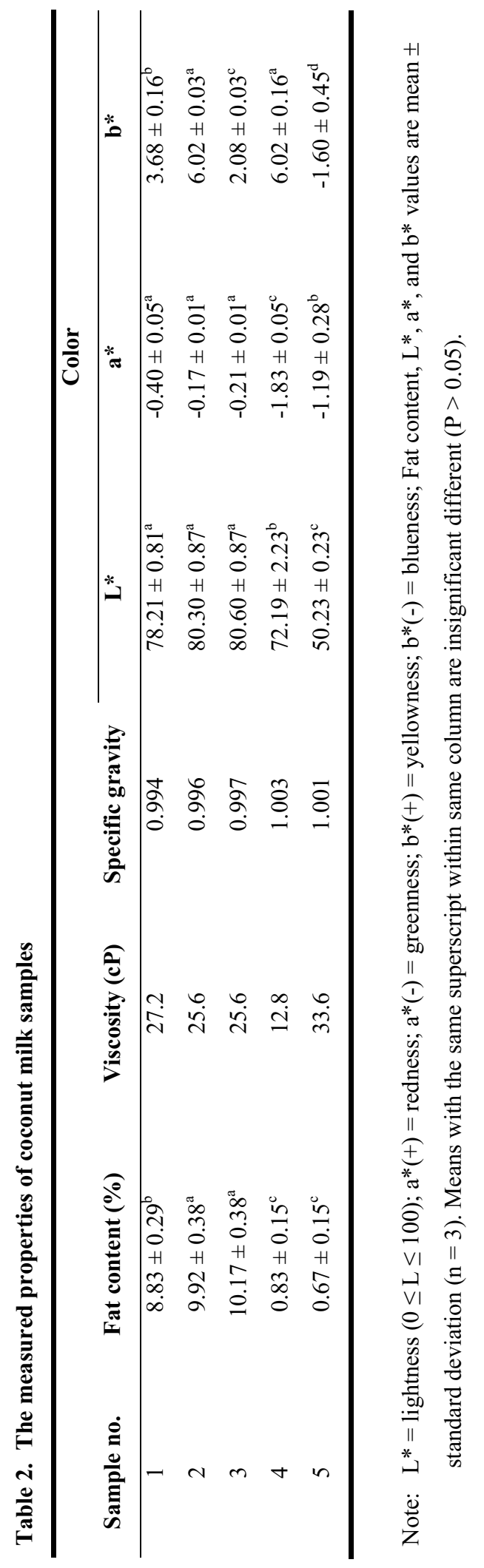


Table 3. The results of cream separation of coconut milk samples no. 1, 3 and 5 .

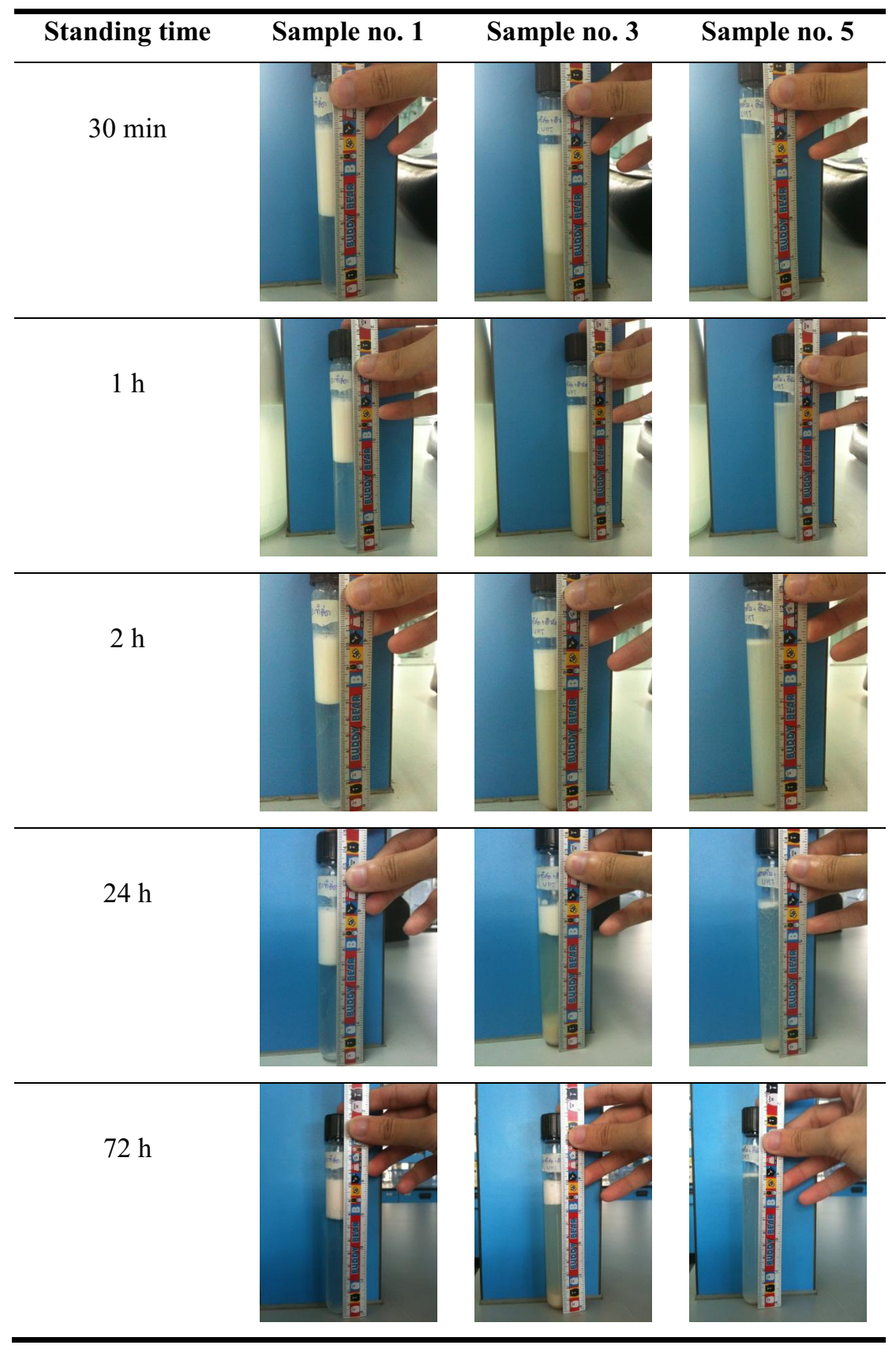


Definitely, the sensory quality is very important for the food product. According to the results in Table 4, the panelists evaluated the blind control to be rather slightly different from the declared control. Likewise the odor of sample no.2-5 was slightly different from control. It showed that the skim coconut milk had different flavor in the same rating as highfat coconut milk. However, these data could not imply the similarity between samples. The color of UHT skim coconut milk (sample no.5) was the most different from the control related to color measurement $\left(\mathrm{L}^{*}, \mathrm{a}^{*}\right.$ and $\left.\mathrm{b}^{*}\right)$ from the colorimeter which showed that UHT skim coconut milk was darker color than other specimens. For taste, texture and overall characteristic, these attributes were slighted and moderated different from control coconut milk. However, it should be noted that, the extent of difference may be the same but the direction may different, particularly "texture" and "overall" attributes. Therefore further experiment is recommended, by using the sensory tests included a preference test followed by a "Just about right" (JAR) test.

Table 4. The sensory test result of coconut milk samples

\begin{tabular}{cccccc}
\hline Sample & \multicolumn{5}{c}{ Sensorial attribute } \\
\cline { 2 - 5 } no. & Color & Odor & Taste & Texture & Overall \\
\hline 2 & $1.60 \pm 1.38^{\mathrm{bc}}$ & $1.49 \pm 2.10^{\mathrm{b}}$ & $2.83 \pm 1.62^{\mathrm{a}}$ & $2.00 \pm 1.39^{\mathrm{a}}$ & $2.43 \pm 1.28^{\mathrm{b}}$ \\
3 & $2.13 \pm 1.57^{\mathrm{b}}$ & $1.45 \pm 1.97^{\mathrm{b}}$ & $3.23 \pm 1.50^{\mathrm{a}}$ & $2.77 \pm 1.34^{\mathrm{a}}$ & $2.83 \pm 1.15^{\mathrm{b}}$ \\
4 & $2.30 \pm 1.53^{\mathrm{b}}$ & $1.66 \pm 3.70^{\mathrm{a}}$ & $3.27 \pm 1.39^{\mathrm{a}}$ & $2.27 \pm 1.51^{\mathrm{a}}$ & $3.57 \pm 1.01^{\mathrm{a}}$ \\
5 & $3.40 \pm 1.52^{\mathrm{a}}$ & $1.44 \pm 2.17^{\mathrm{b}}$ & $2.80 \pm 1.47^{\mathrm{a}}$ & $2.03 \pm 1.25^{\mathrm{a}}$ & $2.93 \pm 1.23^{\mathrm{b}}$ \\
Blind & & & & & \\
control & $1.17 \pm 1.29^{\mathrm{c}}$ & $1.08 \pm 1.07^{\mathrm{c}}$ & $1.30 \pm 1.42^{\mathrm{b}}$ & $1.07 \pm 0.91^{\mathrm{b}}$ & $1.40 \pm 1.30^{\mathrm{c}}$ \\
\hline
\end{tabular}

Note: Sensorial test values are mean \pm standard deviation $(n=30)$. Means with the same superscript within same column are insignificant different $(\mathrm{P}>0.05)$.

\section{CONCLUSIONS}

It is clear that the cream separator can be effectively applied for the production of skim coconut milk product with the remaining fat content of lower than $1 \%$. The addition of the $\mathrm{CMC}$ and Montanox 60 at $0.6 \% \mathrm{w} / \mathrm{v}$ for both additives should be carried out to raise the stability of coconut milk emulsion. The skim coconut milk sample with the addition of CMC and Montanox 60 was slightly more viscous than the coconut milk samples without fat 
separation. The skim coconut milk samples had higher specific gravity and obviously darker than the higher-fat samples. Besides, the sensorial attributes of skim coconut milk samples seemed to be different from the normal coconut milk.

\section{ACKNOWLEDGMENTS}

The authors would like to convey special thanks to Adinop Company for kindly support of emulsifying agent, Montanox 60 in this study.

\section{REFERENCES}

APCC (Asian and Pacific Coconut Community). (1994). International Codes and Standard for Aqueous Coconut Products ( $2^{\text {nd }}$ draft), Jakarta: Standards Task Force, Asian and Pacific Coconut Community, 35-46.

Chanamai, R., \& McClements, D.J. (2000). Prediction of emulsion color from droplet characteristics: dilute monodisperse oil-in-water emulsion. J. Food Sci., 15, 83-91.

Chantrapornchai, W., Clydesdale, F., \& McClements, D.J. (1999). Theoretical and experimental study of spectral reflectance and color of concentrated oil-in-water emulsion. J. Food Sci., 218, 324-330.

Demetriades, K., Coupland, J.N., \& McClements, D.J. (1997). Physicochemical properties of whey protein-stabilized emulsions as affected by heating and ionic strength. J. Food Sci., 62 (3), 462-467.

Ishiaq, O., \& Odeyemi, F.A. (2012). Bio-nutritional constituents of coconut fruit and its possible medicinal applications. Afr. J Plant Sci., 6 (12), 309-313.

Jirapeangtong, K., Siriwatanayothin, S \& Chiewchan, N. (2008). Effects of coconut sugar and stabilizing agents on stability and apparent viscosity of high-fat coconut milk. J.Food Eng., 87, 422-427.

Kleyn, D.H., Lynch, J.M., Barbano, D.M., Bloom, M.J., \& Mitchell, M.W. (2001). Determination of fat in raw and processed milks by the gerber method: collaborative study. J. AOAC. Int., 84 (5), 1499-1508.

Klinkesorn, U., Sophanodora, P., Chinachoti, P. \& McClements, D.J. (2004). Stability and rheology of corn oil-in-water emulsions containing maltodextrin. Food Res. Int. 37, 851-859.

Lamar, P.L., Marks, R.M., \& Amen, R.J. (1976). Factor influencing the emulsion stability of liquid diets. J. Food Sci., 41, 1168-1171. 
Marina, A.M., Che Man, Y.B., \& Amin, I. (2009). Virgin coconut oil: emerging functional food oil. Trends Food Sci. Technol., 20, 481-487.

McClements, D.J. (1999). Food Emulsions: Principles, Practice and Techniques. CRC Press, Boca Raton, p. 378.

Monera, O.D. \& Del Rosario, E.J. (1982). Physico-chemical evaluation of the natural stability of coconut milk emulsion. Ann. Trop. Res., 4, 47-54.

Naik, A., Raghavendra, S.N., \& Raghavarao, K.S. (2012). Production of coconut protein powder from coconut wet processing waste and its characterization. Appl. Biochem. Biotechnol., 167 (5), 1290-1302.

Onsaard, E., Vittayanont, M., Sringam, S., \& McClements, D.J. (2005). Properties and stability of oil-in-water emulsion stabilized by coconut skim milk protein. J. Agri. Food Chem., 53 (14), 5747-5753.

Onsaard, E., Vittayanout, M., Srigam, S. \& McClements, D.J. (2006). Comparison of properties of oil-in-water emulsions stabilized by whey protein isolate. Food Res. Int. 39, 78-86.

Phungamngoen, C., Chiewchan, N., \& Siriwattanayothin, S. (2004). Effect of some stabilizers on the quality of canned high fat coconut milk. KMUTT R\&D J., 27 (3), 375-390.

Raghavendra, S.N. \& Raghavarao, K.S.M.S. (2010). Effect of different treatments for the destabilization of coconut milk emulsion. J. Food Eng. 97, 341-347.

Seow, C.C., \& Gwee, C.N. (1997). Coconut milk: chemistry and technology, Int. J. Food Sci. Technol., 32, 189-201.

Simuang, J., Chiewchan, N., \& Tansakul, A. (2004). Effects of fat content and temperature on the apparent viscosity of coconut milk. J. Food Eng., 64, 193-197.

Sringam, S. (1986). Preparation and stabilization of coconut milk. Food Science and Technology Research Project, Agro-Industry Faculty, Kasetsart University, Bangkok, 25p.

Walstra, P. (2003). Physical Chemistry of Foods. New York: Macel Dekker.

Wattanapahu, S., Suwonsichon, T., Jirapakkul, W., \& Kasermsumran, S. (2012). Categorization of coconut milk products by their sensory characteristics. Kasetsart $J$. (Nat. Sci.), 46, 944-954. 